\title{
A New Model of Green Purchase Intention and its Derivatives: Confirmatory Factor Analysis Validation of Constructs
}

\author{
*Victoria Masi Haruna Karatuํ, Nik Kamariah Nik Mat² \\ ${ }^{1}$ College of Business, Universiti Utara Malaysia, Malaysia \\ ${ }^{2}$ OYA- Graduate School of Business, Universiti Utara Malaysia, Malaysia \\ *victoriaharuna@yahoo.com
}

\begin{abstract}
There are various research frameworks found in the extant literature on green purchase intention. However, there is limited and fragmented comprehensive green purchase intention model in previous studies. Furthermore, the predictor variables and their constructs were diverse and were not tested in Nigeria. This study intends to confirm a comprehensive structural model of purchase intention and validating the constructs in Nigeria. The framework consists of five exogenous predictors (perceived green knowledge, government regulation, perceived value, and price sensitivity, green availability) and four endogenous (green purchase intention, perceived behavior control, environmental consciousness and green trust) Over-all, 76-items measure the variables adapted meticulously from various validated instruments. The questionnaires were distributed to 130 Nigerians in UUM. A return of 104 questionnaires was collected representing $80 \%$ response rate. Analysis methods using descriptive statistics, reliability, confirmatory factor analysis (CFA) in AMOS were conducted. The CFA of individual construct establishes adequate goodness fit of p-value $>0.05$ and GFI of more than 0.90 . The Cronbach alpha also shows values above 0.80 indicating reliable constructs. The measurement model of exogenous and endogenous constructs achieves goodness of fit, indicating convergent validity. The CFA of exogenous constructs ( $p$-value $=0.325, \mathrm{GFI}=0.903$ and RMSEA=0.025) and endogenous constructs $(\mathrm{p}$-value $=0.135$, $\mathrm{GFI}=0.914$ and RMSEA=0.045) show adequate goodness of fit indices. This study is limited to the Nigerian students in UUM only; therefore a study with larger sample is suggested. It implies that this study could provide better understanding of the term "green" among Nigerians. The study will be an impetus to upgrade government policy on green agenda and practitioners too will have insights on what marketing strategies to use in reaching out to potential consumers with green products. Previous studies lack holistic approach to green purchase intention model. The finding indicates that previous measurements could be adapted in Nigerian context.
\end{abstract}

Keywords: Green Purchase Intention, Green Knowledge, Government Regulation, Price Sensitivity, Environmental Consciousness

\section{Introduction}

In recent times, concern for the deplorable state of the environment has increased steadily across the globe. Consumers awareness of the consequences of this threat and the role they need to play for their own well being and to conserve the environment have led to a drastic growth of green products market (Hunt \& Dorfman, 2009). This has been demonstrated in their purchases and consumption as most consumers are now connecting the dots to the environment and their main lifestyle. Consequently, the demands for green products became inevitable (Ali \& Ahmad, 2012; Chen, 2010; Kalafatis, Polland, East \& Tsogas, 1999; Paco \& Raposo, 2009; Rashid, 2009). Gupta and Ogden (2009) confirmed that green products' market size was valued at USD 200 billion in 2006 and another survey by natural (green) marketing institution; reported that over USD 200 billion market of lifestyle of health and sustainability (LOHAS) rose by $100 \%$ in 2010 and was expected to rise four times bigger by 2015 (Widger, 2007). Furthermore Jones, Shrinivas, and Bezner-Kerr (2014) acknowledged that the global market for green product marketing is expected to rise to US $\$ 3.5$ trillion by 2017 due to the alarming rise in awareness on environmental issues. However, in some developing countries this trend is quite new as some regions are still in the dark, and low awareness about green products is an issue of concern, (Synovate survey, 2012). Relating it specifically to the Nigeria society, survey revealed that just $5 \%$ of Nigerians are engaged in green purchase behavior (Quick pulse, 2011). Attesting to this, Olamiyu (2012) opined in his discussion on preparing the Nigerian Market for Green Products that only those in the upper and upper-middle classes have started directing their brand choices towards green; and equally emphasized that green is not yet a widespread phenomenon in Nigeria. 
Seemingly, Nigeria has a fast developing economy and the citizens are also fast changing in their social lifestyle, this makes Nigeria a big opportunity for green product marketing. But lack of adequate information on green product, its high price as noted by other consumers in other nations and its availability in the market may pose a challenge to the consumers (Bonini \& Oppenheim, 2008; Grailresearch, 2010). Moreover, to most Nigerians purchasing a green product will be third most important and considered as a luxury because they are wearied with other pressing issues of life such as housing, education and food. Besides, although studies on green purchase intention have been conducted in different context, especially in developed countries different drivers of green purchase intention were used, having fragmented models and results too were inconsistent- such results cannot be generalized; not only because of their inconsistencies but also due to variations in cultural, socio- demographic, geographical setting and consumer behavior complexity. To buttress this, studies confirmed that demand and purchase behavior towards environmental friendly products often differ on the basis of market and cultural factors, (Elham \& Nabsiah, 2011; Ottman, 1992; Peattie, 1992). The need for a study on green purchase intention in Nigeria, therefore is pertinent in order to examine the effect of the selected variables (Environmental consciousness, Green Trust, Perceived Behavioral Control, and Perceived Value, Green Availability, Price Sensitivity, Government Regulation and Perceived Green Knowledge) on green purchase intention Consequently, this study has been chosen to establish a comprehensive structural model of green purchase intention and to validate the constructs in Nigeria

\section{Literature Review}

Green purchase intention is a specific environmental friendly action portrayed by the consumer indicating that they have a concern for the environment. Bagozzi (1983) suggested that a willful state of mind in which the person makes a choice or a statement for a future course of action is referred to as purchase intention and it is a very significant factor which serve as proxy to actual purchase (Ramayah, Lee \& Mohammed, 2010) .Likewise, Fishbein and Ajzen (1975) explained that intention is a subjective likelihood about a person's valuation on how he /she will carry out a specific behavior. Elucidating further, Ajzen (2002) stated that behavioral intentions reveal human activities that are guided by three different types of considerations which are; behavioral belief, normative belief and control belief. The concept of green purchase intention in this study is explained as the possibility and willingness of an individual to give preference to brands of products/services which have environmentally safe characteristics in their purchase decision. Studies on green purchase intention showed that intention is a strong predictor of green purchase behavior as intention strongly affects the likelihood of decision to buy the product (Chen, 2010). Researchers who examined this variable have proved that it exerts strong and significant influence on actual purchase; this buttressed the fact that someone with positive intention is likely to go for the green product when compared with a person with low intentions (Ali, Khan, Ahmed \& Shahzad, 2011).

Apparently, the review of extant literature indicated that models are limited, fragmented and often have direct relationship. Hence, determinants of green purchase intention as suggested by different authors taking a few examples; attitude (Azizan \& Suki, 2013; Ling, 2013; Mei, Ling \& Piew ,2012; Shamsollahi, Chong \& Nahid, 2013; Tan, 2013; Zakersalechi \& Zakersalechi, 2012; Zhu, 2013), consumer knowledge was tested as direct antecedent of green purchase intention (Aman, Harun \& Hussien, 2012; Ali \& Ahmad, 2012; Wu, Huang \& Teng, 2013). Likewise, environmental concern from the point of (Ali \& Ahmad, 2012; Ahmad \& Juhdi, 2010; Kim \& Han, 2010; Lee, Ling, Yeow, Hassan \& Arif, 2011; Numraktrakul, Ngarmyarn \& Panichpathom, 2011; Shamsollahi et al., 2013) could directly influence the intention to purchase green product. Furthermore, Mahesh and Ganapathi (2012) and Maya, Lopez-Lopez \& Munuera (2011) suggested that perceived behavioral control can serve as both a direct determinant of green intention and also a mediating variable. Perceived value equally played a significant role as opined by these authors when used as a direct predictor (Chen \& Chang, 2012; Paspalis, 2011; Rizwan, Hassan \& Javeed, 2013). Another strong predictor of green purchase intention understood from previous studies is trust (Gupta \& Dash, 2012; Pornpratang, Lockard, \& Ngamkroeckjoti, 2013).Subsequent studies indicated that corporate social responsibility is another antecedent of green purchase intention (D'Souza, Taghian \& Lamb, 2009; Lee \& Shin, 2008).

Also, willingness to pay was examined as one of the variables that could have affiliation with green product (Ansar, 2013; Ali \& Ahmad, 2012; Ling, 2013; Numraktrakul et al., 2011; Zhen \& Mansori, 2012). Additionally, Ansar (2013) believed that green purchase can be impacted by socio-demographic, 
environmental advertising and ecological packaging. While Ling (2013) explained the significant relationship between store image and roles of the sales person in connection with green purchase intention. Moreover, health consciousness was examined by (Azizan \& Suki, 2013; Ahmad \& Juhdi, 2010; Shamsollahi et al, 2013). Likewise, environmental labeling was considered (Azizan \& Suki, 2013; Mei et al., 2012). Further confirmation of this fragmentation is seen as perceived value was studied by (Lee et al., 2011; Rizwan, et al., 2013; Shamsollahi et al., 2013). Additionally, government support and policy (Ahmad \& Juhdi, 2010; Mei et al., 2012; Numraktrakul et al., 2011; Shamsollahi et al., 2013) featured as a direct determinant of green purchase intention. Due to the fact that these authors take a different stand when it comes to determining the antecedents of green purchase intention, the models have most of the time been fragmented with no holistic standard for what should be called Green Purchase Intention Determinants nor Model; thus, diversities in antecedents and contradictions in the findings on relationship was inevitable. Moreover, the conspicuous absence of model in the Nigeria context in green setting strongly necessitated having a study of this nature to fill the gap by expanding knowledge and literature in this sensitive area of green concept.

\section{Discussion on Items}

Green Purchase Intention (GPI): Green Purchase intention was measured using six items which were drawn from a combination of items from different scholars. The scales were developed and selected in the following order. From the study of Pornpratang et al. (2013) one item was taken and another one from Mei et al. (2012). Further, two items were adapted from the study of Chen and Chang (2012) with Craonbach reading of 0.859 . In order to complete the required number of items, one item each were adapted from Zhen and Mansori (2012), (Cronbach 0.851) and Shamsollahi et al. (2013); (no Cronbach reading).

Environmental Consciousness (EC): This variable has limited studies, thus measurement items which could be appropriate in the context of this study were scarce. Most items were structured by the authors except two which were adapted from (Gould, 1990; Numraktrakul et al., 2011). Item (i) was after the works of (Numraktrakul et al, 2011) while item (4) was adapted from (Gould, 1990)

Green Trust (GT): In order to measure trust three items were modified and adapted from Chen and Chang (2012); based on their study on enhancing green purchase intention the value of the Cronbach was 0.902. One more from the study of Tan and Teo (2000) with Cronbach reading of 0.93 ; lastly, the study conducted by Flavian, Guinaliu and Torres (2005) provided measurement on trust, hence, two additional items were adapted though without Cronbach Alpha reading.

Perceived Behavioral Control (PBC): The measurement was based on existing scales operationalized by the following authors; Tan (2013), two items with cronbach reading of 0.881; Numraktrakul et al. (2011) two items and the Cronbach reading was 0.776; and one each from Wang, Wiegerinck, Krikke and Zhang (2013) Cronbach 0.859; and Lim, Yap and Lee (2011), Cronbach reading was not available. All were adapted with the hope that the reliability reading in this study will also be of an acceptable level as these ones.

Green Perceived Value (GPV): In addition to the other variables for this study, six items also measured Perceived Value out of which the first two were adapted from Chen and Chang (2012) and the coefficient from the analysis was 0.882. Furthermore, additional item was selected from Shamsollahi et al. (2013). The Cronbach alpha for this study, however, was not accessed. In the same vein, one more item was taken from Jaafar, Lalp and Naba (2012) and two additional items from Vahie and Paswan (2006) which also did not have Cronbach alpha.

Green Price Sensitivity (GPS): The scale of measurement for price sensitivity includes nine items selected on the basis of previous validated instruments used by (Jain \& Srivastava, 2000; Numraktrakul et al., 2011; Zhen \&Mansori 2012). Three items were adapted respectively from each. The first three items were selected from Zhen and Mansori (2012) Cronbach alpha value 0.568.The other three were selected from Numraktrakul et al. (2011) from the study on intention to purchase greenhouse in Thailand. The remaining three items were meant to test consumers' sensitivity to green price (Jain \& Srivastava, 2000) these items in previous studies produced reliability value of 0.82 . Standing on the fact that both works were on green purchase intention and the instruments were validated, the items if tested in this study will show valid result. 
Green Availability (GAV): Measurement items for the variable were established from existing validated items used by (Zhen \&Mansori, 2012). All the items were adapted based on their relevance to the current study and because of the difference in geographical setting. The reliability reading was of acceptable level; the reading was 0.571.Furthermore, two items were adapted from the study of Tarkianen and Sundqvist (2005) and Cronbach was 0.782. Due to the fact that the variable was to be measured with six items, the remaining three were adapted from the study Olivova (2011), with reliability coefficient of 0.774 .

Government Regulations (GR): Government regulations have six items just like the other variables and were adapted from three different authors. Respectively, two items were taken from (Numraktrakul et al., 2011) and the value of Cronbach was 0.827. Another two were adapted from (Mei et al, 2012) with 0.775 as reliability reading. In order to make the investigation more exhaustive, additional two items were included from the study of (Tan \& Teo 2000).

Perceived Green Knowledge (PGk): Perceived Green Knowledge was measured using twelve items scale adapted from (Mukherjee \& Hoyer, 2001; Roehm \& Sternthal, 2001; Sakthirama \& Venktram, 2012; Zhen \&Mansori, 2012).Following (Mukherjee \& Hoyer, 2001) study, the researcher adapted three items and Cronbach was 0.81. Additionally, three items were adapted from (Roehm \& Sternthal, 2001) with reliability of 0.81. Based on the work of Sakthirama and Venkthram (2012) one item was used and the reliability value was 0.802 .Three were adapted from Zhen and Mansori (2012) with Cronbach reading of 0.747 .

\section{Methodology}

The research design for this study uses the survey method to enable the collection of data which can answer certain questions that pertain to the study and to find out trends in consumer behavior towards green purchase intention (Hair, Bush \& Ortinau, 2000; Hair, Black, Babin \& Anderson, 2010).This method is chosen because of its credibility in the collection of a vast range of relevant information which can be relied upon as respondents have restricted options stated in the questionnaire (Rindfleisch, Malter, Ganesan \& Moorman, 2008). The sample for this study is the Nigerian Students Community in University Utara Malaysia. A total of 130 questionnaires were distributed randomly and 104 usage able questionnaires were returned, indicating a response rate of $80 \%$. Measurement for all constructs developed for this study comprises of five independent variables which are Perceived Green Knowledge (PGK, 12 item), Green Perceived Value (GV,6item), Green Availability (GAV,6item), Green Price Sensitivity (GPS,9item), Government Regulations (GR,6item) and three mediating variables, Environmental Consciousness (EC,6item), Perceived Behavioral Control (PBC, item) and Green Trust (GT,6item), and one dependent variable which is Green Purchase Intention (GPI, 6item).

Accordingly, measurement scale is very vital in choosing the right statistical test. Variables can be measured and conveyed in different scales, but the most commonly used measurement scale in social and behavioral science research is the Likert scale, (Nanna \& Sawilowsky, 1998). Mostly, Likert-type scale is preferred because it is easy to analyze statistically (Jackson, 2009). Hence, the measurement scale for this study is based on seven-point Likert scale (1-strongly Disagree; 2-Disagree; 3-Somewhat Disagree; 4-Neutral; 5-Somewhat Agree; 6-Agree; 7-Strongly Agree). Consequently, this study utilizes descriptive statistics and analysis method. The validation analysis of instrument is conducted through Cronbach alpha (SPSS) and confirmatory factor analysis (CFA-AMOS). Also, convergent validity via confirmatory factor analysis. All 104 data were entered into SPSS spreadsheet ready to be validated (Tabachnick \& Fidell, 2007).

\section{Findings}

Demographic Profile: The result of the demographic profile revealed that (73.1\%) of the respondents are male while $(26.9 \%)$ are female, indicating that the male are the majority .Most of the respondents are students in second semester (35.9\%). Majority, (25\%) are studying accounting, (19\%) are for IT, (13\%) are in the department of economics, $(28 \%)$ are in different other programs. The educational statistics indicated that (46.2\%) are PhD students, $29.8 \%$ ) degree students, Msc, (21.2\%), MBA, only (2\%). The residential result showed that (88.5\%) are from the urban area while (11.5\%) are from the sub-urban. Following the result on income, the monthly take home income shows that (37.5\%) fall within low income and 35\% with high income. The remaining are in the category of middle income. Among the 
respondents, Senior lecturers are only (16.3\%); the highest are those in other ranks which is denoted by $(65.4 \%)$ while the least is $(1.0 \%)$.

Reliability of Result (Cronbach alpha) of Constructs: The constructs have been tested for reliability and found to have reliable Cronbach alpha reading above 0.80 with the exception of green price which is less than 0.8. According to Nunnally (1970) the value of 0.60 is still within the acceptable limit. The exact alpha values for each of the variables are: Green Purchase intention (0.911), Environmental consciousness (0.824), Perceived Behavioral Control (0.815), Green Trust (0.889), Perceived Green Knowledge (0.829), Perceived Value (0.825), Green Price (0.743), Government Regulations (0.835) and Green Availability (0.824).

Convergent Validity (Confirmatory Factor Analysis): The confirmatory factor analysis (CFA) was conducted on all the constructs and measurement models which turned out to have a goodness of fit with the data following the criteria assessment: CMIN $\backslash$ df ratio $(<2)$; the p-value $(>0.05)$., GFI of $>0.95$; root mean square error of approximation (RMSEA) produced values less than $0.08(>0.08)$ (Bagozzi \& Yi, 1988; Hair, Black, William, Anderson \& Rolph,2006) For instances, green purchase intention (CMIN $\backslash \mathrm{df}=1.598, \quad \mathrm{p}$-value $=0.202, \mathrm{GFI}=0.985, \mathrm{TLI}=0.982$, RMSEA $=0.076$ ); ; $(\mathrm{CMIN} \backslash \mathrm{df}=1.464, \mathrm{p}$-value $=0.231, \mathrm{GFI}=0.986, \mathrm{TLI}=0.981, \mathrm{RMSEA}=0.046)$, green trust $(\mathrm{CMIN} \backslash \mathrm{df}=1.570$, p-value $=0.208, \mathrm{GFI}=0.985, \mathrm{TLI}=0.980, \mathrm{RMSEA}=0.074)$; perceived behavioral control(CMIN $\backslash \mathrm{df}=1.361, \mathrm{p}$-value $=0.236, \mathrm{GFI}=0.976, \mathrm{TLI}=0.991, \mathrm{RMSEA}=0.070)$; government regulations $($ CMIN $\backslash \mathrm{df}=1.578, \mathrm{p}$-value $=0.206, \mathrm{GFI}=0.982, \mathrm{TLI}=0.983, \mathrm{RMSEA}=0.075) ;$ perceived green knowledge (CMIN $\backslash \mathrm{df}=1.300, \quad \mathrm{p}$-value $=0.272, \mathrm{GFI}=0.987, \mathrm{TLI}=0.991, \quad \mathrm{RMSEA}=0.027$ ); perceived value (CMIN $\backslash \mathrm{df}=1.137, \mathrm{p}$-value $=0.338, \mathrm{GFI}=0.979, \mathrm{TLI}=0.989, \mathrm{RMSEA}=0.036)$; green price sensitivity (CMIN $\backslash \mathrm{df}=1.068, \mathrm{p}$-value $=0.382, \mathrm{GFI}=0.964, \mathrm{TLI}=0.992, \mathrm{RMSEA}=0.026)$; green availability $(\mathrm{CMIN} \backslash \mathrm{df}=1.135, \mathrm{p}$-value $=0.339, \mathrm{GFI}=0.903, \mathrm{TLI}=0.991, \mathrm{RMSEA}=0.036)$.

The goodness of fit of the exogenous measurement model, (perceived green knowledge, perceived value, government regulations, green price, green availability) $\mathrm{CMIN} \backslash \mathrm{df},=1.065, \mathrm{p}$-value $=0.325, \mathrm{GFI} .=0.903$, TLI $=0.991$ and RMSEA $=0.025$. Also, endogenous model achieved its fit, (green purchase intention, environmental consciousness, green trust and perceived behavioral control) CMIN $\backslash$ df, 1.204, p-value 0.135, GFI 0.914, TLI 0.970 and RMSEA, 0.045, (Hair et al, 2006). The confirmatory factor analysis results indicate that all construct achieved goodness of fit after a few deletions were made on the constructs; green purchase intention, environmental consciousness, green trust, government regulations, had two items deleted out of the six ( 64 item).Likewise, green price had two item deleted from the nine initial item (9-7item).On the other hand, perceived behavioral control, perceived value and green availability had only one item deleted,(6-5items).Perceived green knowledge however was left with four items out of twelve original items (12-4 items).

Discussion: The study identifies five exogenous variables,(perceived green knowledge, government regulations, perceived value, green availability, green price sensitivity); endogenous variable, (green purchase intention) and three mediating variables (perceived behavioral control, environmental consciousness and green trust) to test green purchase intention using these validated constructs in the Nigeria context. Based on the output for individual models of all the constructs, all the Cronbach's alpha coefficients are more than above 0.70 .This equally is in line with coefficient values of the previous studies (Chen and Chang 2012; Mukherjee \& Hoyer, 2001; Numraktrakul et al, 2011; Roehm \& Sternthal, 2001; Sakthirama \& Venktram, 2012). The lowest is green price (0.743) when compared with Chen and Chang (2012) which had Cronbach value of (0.0568).The highest is GPI which is (0.911).Again, comparing the reliability to previous studies with reliability reading of 0.859 (Chen \& Chang 2012) and 0.851, (Chen \& Chang, 2012) the Cronbach Alpha for this study are higher. Also, the reading for Cronbach in this study, (0.889) appears to be lower than Chen and Chang,(2012). In a nutshell, most of the Cronbach alpha from past studies were within the reading of 0.0571- 0.902. The lowest is government regulation (0.571) and the highest, green trust (0.902). While the lowest in this study is green price (0.743). Fundamentally, the green marketing activity is vital to the Nigerian economy and also for the well-being of the nation. On this note, the outcome of this study certainly will heighten adoption of green purchase and consumption in green agenda in Nigeria. The upshot thus forms an impetus for the increase in Environmental consciousness and government enforcement of environmental laws. Through this investigation, consumers will be adequately informed about green products as evidences pointed to the fact that knowledge and awareness on green is very low. 


\section{Conclusion}

The study has indicated that the measurement items are adequate to be used for the study at hand and capable of producing positive result as they did in the other contexts. This is inferred from the output of the confirmatory factor analysis which revealed acceptable values of reliability.

\section{References}

Ahmad, S. \& Juhdi, N. (2010). Organic Food: A Study on Demographic. Characteristics and Factors Influencing Purchase Intentions among Consumers in Klang Valley, Malaysia. International Journal of Business and Management, 5 (2).

Ajzen, I. (2002). Perceived Behavioral Control, Self-Efficacy, Locus of Control and. The Theory of Planned Behavior. Journal of Applied Social Psychology, 32(4), 665-683.

Ali, A. \& Ahmad, I. (2012). Environmental Friendly Products: Factors that Influence the Green Purchase Intention of Pakistan Consumers. Pakistan Journal of Engineering Technology Science, 2(1) 84-117.

Ali, A., Khan A. A., Ahmed, I. \& Shahzad, W. (2011). Determinants of Pakistani. Consumers Green Purchase Behavior: Some Insights from a Developing Country. International Journal of Business and Social Science, 2(3), 217-226.

Aman, A. H. L., Harun, A. \& Hussein, Z. (2012). The Influence of Environmental. Knowledge and Concern on GreenPurchase Intention the Role of Attitude a Mediating Variable. British Journal of Arts and Social Sciences, 7(I1), 145-167

Ansar, N. (2013). Impact of Green Marketing on Consumer Purchase Intention. Mediterranean Journal of Social Sciences, 4(11), 650.

Azizan, M. \& Suki, N. M. (2013). Consumers Intention to Purchase Green Product: Insights. From. Malaysia. Labuan School of International Business and Finance Universiti Malaysia, 22(8), 1129-1134.

Bagozzi, R. P. (1983). A Holistic Methodology for Modeling Consumer Response to Innovation. Operations Research, 31,128-176.

Bagozzi, R. P. \& Yi, Y. (1988). On the evaluation of Structural equation models. Journal of the Academy Marketing Science, 16, 74-94

Bonini, S. \& Oppenhiem, J. (2008). Cultivating the Green Consumer. Stanford Social Innovation $10^{\mathrm{TH}}$ Review Anniversary. 1-10.

Chen, Y. S. (2010). The Drivers of Green Brand Equity: Green Brand Image, Green Satisfaction, and Green Trust. Journal of Business Ethics, 93(1), 81-92.

Chen, Y. \& Chang, C. (2012). Enhance Green Purchase Intentions: The Roles of Green Perceived Value, Green Perceived Risk, and Green Trust. Management Decision .Emerald Group Publishing, 50(3), 502-520.

D'Souza, C., Taghian, M. \& Lamb, P. (2009). An Empirical Analysis of Australian and Portuguese. Consumers within. The Context of CSR and Environmentalism. In ANZMAC Sustainable Management and Marketing. Australian and New Zealand Marketing Academy Conference, 1-8.

Elham, R. \& Nabsiah, A. W. (2011). Investigations of Green Marketing Tools Effect on Consumers Purchase Behavior. Business Strategy series, 2, 73-83.

Flavian, C., Guinaliu, M. \& Torres, E. (2005).The Influence of Corporate Image on. Consumer Trust: A Comparative analysis in Traditional verses Internet Banking. Internet Research, 15(4), 447-470

Fishbein, M. \& Ajzen, I. (1975). Belief, attitude, intention and behavior: An introduction to Theory and Research.

Grailresearch. (2010). Http://www.grailresearch.com/pdf/contenPodsPdf/TheRevolution.Pdf.(Accessed July,2013

Gould, S. (1990). Health Consciousness and Health Behavior: The Application of New Health Consciousness Scale. American Journal of Preventive Medicine, 6(4), 228-37

Gupta, A. \& Dash, S. B. (2012). Encouraging Green Consumption: Role of Green Trust and Green Experiential Value.wsnconfrence.com/downloads/wsmpresentations/Sunday/AnshaGupta-Gree Experience, Pdf. Retrieved7/10/2013.

Gupta, S. \& Ogden, D. T. (2009).To Buy or Not to Buy? A Social Dilemma Perspective on Green Buying. Journal of Consumer Marketing, 26(6), 376391.

Hair, J. F., Bush, R. P. \& Ortinau, D. J, (2000). Marketing Research: A Practical Approach for the New Millennium, McGrawHill USA. 
Hair, J. F., Black, C., William, A. \& Rolph, E. (2006). Multivariate DataAnalysis, $7^{\text {the }}$ dition,availableathttp://www.mediafire.com/?mkrzm monn Retrieved 1 December 2013.

Hair, J. F., Black, W. C., Babin, B. J. \& Anderson, R. E. (2010). Multivariate Data Analysis, 6th Edition. NJ: Prentice-Hall International.

Hunt, N. \& Dorfman, B. (2009). How Green is My Wallet? Organic food growth slows. Reuters. Retrieved from http://www.reuters.com

Jackson, S. L. (2009). Research Methods and Statistics: A Critical Thinking Approach 3 rdedition.Belmont, CA:Wadsworth.http://psychcentral.com/blog/archives/2011/09/27/the-3-basic-types-of-de

Jaafar, S. N., Lalp, P. E. \& Naba, M. M. (2012). Consumers ' Perceptions , Attitudes and Purchase Intention towards Private Label Food Products in Malaysia. Asian Journal of Business and Management Science, 2(8), 7390

Jain, S. \& Srivastava, J. (2000). An Experimental and Theoretical Analysis of Price Matching Refund Policies. Journal of Marketing Research, 37(3),351-362

Jones, A. D., Shrinivas, A. \& Bezner-Kerr, R. (2014). Farm production diversity is associated with greater household dietary diversity in Malawi: Findings from nationally representative data. Food PolicyJournal-Elsevier, 46, 1-12

Kalafatis, S. P., Pollard, M., East, R. \& Tsogas, M. H. (1999). Green Marketing and Ajzen's Theory of Planned Behavior: A Cross-Market Examination. Journal of Consumer Marketing, 16(5), 441-460.

Kim, Y. \& Han, H. (2010). Intention to Pay Conventional-Hotel Prices at a Green Hotel A Modification of the Theory of Planned Behavior. Journal of Sustainable Tourism, 18(8), 997-1014.

Lee, K. \& Shin, D. (2008). Consumers ' Responses to CSR Activities: The linkage between Increased Awareness and Purchase Intention .Public Relations Review, 36(2), 193-195.

Lee, C., H., Ling, H. Y., Yeow, J., Hasan, A. \& Arif, M. (2011). The Influence of Green Consumption Cognition of Consumers on Behavioral Intention-A case study of the Restaurant Service Industry. African Journal of Business Management, 6(26), 7888-7895.

Lim, Y. M., Yap, C. S. \& Lee, T. H. (2011). Intention to Shop Online : A study of Malaysian Baby Boomers, African Journal OF Business Management, 5(5), 1711-1717

Ling, C. Y. (2013). Consumers Purchase Intention of Green Products : An Investigation of the Drivers and Moderating Variable, Elixir. International Journal Marketing Management, 57A. 14503-14509.

Mahesh, N. \& Ganapathi, R. (2012).Influence of Consumer's Socio-Economic Characteristics and Attitude on Purchase Intention of Green Products. International Journal of Business and Management, 4(5), 33-37.

Maya, R. S., López-López, I. \& Munuera, J. L. (2011). Organic food Consumption in Europe: International segmentation based on value system differences. Ecological Economics, 70(10), 1767-1775.

Mei, O. J., Ling, K. O. \& Piew, T. H. (2012). The Antecedents of Green Purchase Intention among Malaysian Consumers. Asian Social Science, 38, 246.

Mukherjee, A. \& Hoyer, W. D. (2001). The Effect of Novel Attributes on Product Evaluation. Journal of Consumer Research, 28(12), 462-472

Nanna, M. J. \& Sawilowsky, S. S. (1998). Analysis of Likert Scale Data in Disability and Medical Rehabilitation Research. Psychological Methods, 3, 55-67.

Nunnally, J. C. (1970). Introduction to Psychological Measurement. New York McGraw-Hill.

Numraktrakul, P., Ngarmyarn, A. \& Panichpathom, S. (2011). Factors Affecting Green Housing Purchase, 111.www.wbiconpro.com/508.Atcharawan.pdf.Retrieved 9/10/2013.

Olivová, K. (2011). Intention to Buy Organic Food among Consumers in the Czech. Republic.

Olamiyu, E. (2012) Preparing Nigerian Market for Green Products. National Mirrow.29/3.2013. Retrieved $5 / 19 / 2013$.

Ottman, J. (1992). Sometimes consumers will pay more to go green. Marketing News, 26, 6-16.

Paco, A. D. \& Raposo, M. (2009). Green Segmentation: An application to the Portuguese Consumer market. Marketing Intelligence and Planning, 27(3), 364-379

Paspalis, E. (2011). Enhancing the Green Purchase Intention Based on Green Marketing: An Empirical Study from Pakistan. American Journal of Civil Engineering and Environment, 1(4), 1-8.

Peattie, K. (1992). Green Marketing. London: Pitman.

Pornpratang, K., Lockard, D. \& Ngamkroeckjoti, W. (2013). The Impact of Corporate Social Responsibility(CSR) on Consumer Trust and Purchase Intention : A Case Study of Condominium Development in Bangkok Area,(March).International Conference on Business, Economics and Accounting 
Quick Pulse Green Buying. (2011). An Exploration of Green Consumer Trends an Analyst Insight from

Euro monitors International.http://blog.euromonitor.comquick-pulse.green-buying-an-exploration-of green consumertrends.html Retrieved 4/10/2013

Ramayah, T. J., Lee, W. C. \& Mohamad, O. (2010). Green Product Purchase Intention: Some Insights from a Developing Country. Resources, Conservation and Recycling, 54(12), 1419-1427.

Rashid, R. N. A. (2009). Awareness of Eco-label in Malaysia's Green Marketing Initiative. International Journal of Business and Management, 4(8), 132-41.

Rizwan, M., Hassan, M. \& Javeed, U. (2013). Future of Green Products in Pakistan : An Empirical Study aboutGreen Purchase Intentions, Asian Journal of Empirical Research, 3(4), 87-100

Rindfleish, A., Malter, A. J., Ganesan, S. \& Moorman, C. (2008). Cross-Sectional versus. Longitudinal survey: Concepts, Findings and Guidelines. Journal of Marketing Research, 45(3)261-79

Roehm, M. L. \& Sternthal, B. (2001). The Moderating Effect of Knowledge and Resources on the Persuasive Impact of Analogies. Journal of Consumer Research, 28(9), 257-272.

Sakthirama V. \& Venkatram, R. (2012). A Structural Analysis of Purchase Intention of Organic Consumers. International Journal of Management, 3(2), 401-410

Shamsollahi, A., Chong, C. W. \& Nahid, N. (2013). Factors Influencing on Purchase, Behavior of Organic Foods. Journal of Human and Social Science Research, 1(2), 93-104.

Synovate Survey. (2012). Reveals Latest Green Habit and Consumption across the World.www.Iposs-na-com/newspolls/pressrelease.aspx?id.Retrieved4/10/2013

Tan, M. \& Toe, T. S. H. (2000). Factors Influencing the Adoption of Internet Banking. Journal of the Association for Information System, 1(5), 1-42.

Tan, T. H. (2013). Use of Structural Equation Modeling to Predict the Intention to. Purchase Green and Sustainable Homes in Malaysia. Asian Social Science, 9(10), 181-191

Tabachnick, B. G. \& Fidell, L. S. (2007). Using Multivariate Statistics: Pearson Education Inc. Boston, MA

Tarkianen, A. \& Sundqvist, S. (2005). Subjective Norms, Attitudes and Intentions of Finnish Consumers in Buying Organic Food. British Food Journal, 107(11), 808-822

The Lohasian. (2010). Inside Eastern Europe's Organic Food Boom Portal on Lifestyle of Health and. Sustainability. Retrieved Oct 16, 2013 from www.thelohasian.com

Vahie, A. \& Pasw, B. (2006 ). Brand. International Journal of Retail and Distribution Management, $\quad 34(1)$ 67-84

Wang, Y., Wiegerinck, V., Krikke, H. \& Zhang, H.(2013). Understanding the Purchase. Intention towards Remanufactured Product in Closed-Loop Supply Chains. An Empirical Study of China. International Journal of Physical Distribution \& Logistics Management, 43(10). Emerald Group Publishing .866-888

Wu, K., Huang, D. \& Teng, Y. (2013). Environmental Concern, Attitudes and Intentions towards Patronage of Green Restaurants. Life Science Journal, 10(4), 2329-2340.

W.W.W. Quick Pulse: Green Buying -An Exploration of Green Consumer Trends... http://blog.euromonitor.com/2012/03/quick-pulsewww.Euromonitor,,2010;2011. Retrieved October, 2013

Widger, D. (2007). Green Consumer Behavior- Part1: Information Paradox. Marketing Green Retrieved 12/12/ 2013. Euro international survey of $80+$ countries

Zakersalehi, M. \& Zakersalehi, A. (2012). Consumers Attitude and Purchasing Intention towards green packaged foods; A Malaysia Perspective: Economics Marketing and Management, IPEDR, (28) IACSIT Press, Singapore.

Zhen J. S. S. \& Mansori, S. (2012). Young Female Motivation for Purchase of Organic. Food in Malaysia. International Journal of Contemporary Business Studies, 3(5), 61-72.

Zhu, B. (2013). The Impact of Green Advertising on Consumer Purchase Intention of Green Products. World Review of Business Research, 3(3), 72- 80. 